\title{
Kolaborasi Stakeholder pada Pelaksanaan Inovasi Penanggulangan Bencana Gempa Bumi di Nusa Tenggara Barat Tahun 2018
}

\section{Stakeholder Collaboration on the Implementation of Innovation in Earthquake Disaster Management in West Nusa Tenggara in 2018}

\section{Suryanuddin'1, Annisah²}

${ }^{1}$ Kementerian Koordinator Bidang Pembangunan Manusia dan Kebudayaan

2 Universitas Indonesia

\section{Penulis Korespondensi}

Suryanuddin

suryanuddin_86@yahoo.com +6281315252211

\begin{abstract}
Abstrak
Inovasi yang dilakukan pemerintah dalam menangani bencana gempa bumi Nusa Tenggara Barat (NTB) 2018 menghadapi sejumlah tantangan. Pembangunan rumah ditargetkan selesai dalam satu tahun, dua tahun berjalan masih belum tuntas. Data ganda, tidak terserapnya dana, hingga jumlah rumah terbangun belum sesuai target menjadi masalah serius. Padahal, stakeholder yang terlibat sangat banyak. Pada awal trimester 2021, pembangunan Rumah Tahan Gempa (RTG) di semua wilayah NTB di atas 97\%. Untuk itu, menarik untuk dikaji lebih lanjut bagaimana inovasi penanggulangan bencana di NTB dapat mencapai target dan bagaimana peran stakeholder yang ada. Kajian ini dilakukan berdasarkan studi dokumen dari dokumen pemerintah pusat dan daerah serta literatur review artikel jurnal selama April 2021. Hasil kajian menunjukkan bahwa intensifnya kolaborasi dan sinergi dari berbagai stakeholder, berperan besar dalam mengatasi permasalahan yang ada. Validasi data yang dilakukan BRI berperan besar dalam mengatasi dana ganda. Desain RTG dari Kementerian PUPR memudahkan masyarakat dalam merencanakan dan membangun kembali rumahnya. TNI mempercepat pembangunan RTG. Fasilitator membantu masyarakat dalam perencanaan, pengajuan dana, pelaksanaan, hingga pelaporan. Berbagai upaya ini membuat permasalahan yang dihadapi saat inovasi penanggulangan bencana teratasi. Setiap stakeholder memiliki peran yang sama besar dan sama pentingnya dalam menyinergikan dan mengolaborasikan semua stakeholder untuk mendukung tercapainya tujuan penanggulangan bencana.
\end{abstract}

\section{Kata Kunci}

gempa bumi; rehabilitasi; rekonstruksi; stakeholder; rumah tahan gempa 


\begin{abstract}
Innovations made by the government in dealing with the 2018 West Nusa Tenggara earthquake disaster (NTB) face several challenges. Construction of the house is targeted to be completed within a year, but the two-year run is still not completed. There are double data, not absorbed funds, until the number of houses built has not been in accordance with target becomes a serious problem. In fact, the stakeholders involved are very much. At the beginning of the quarter of 2021 reported the construction of earthquake resistant houses (RTG) in all NTB areas above $97 \%$. Therefore, it is interesting to be further reviewed how the success of disaster management breakthroughs in NTB can achieve the targets and roles of various stakeholders. This study was conducted based on the study of documents from central and local government documents as well as literature reviews from journal articles during April 2021. The results of the study showed that the intensive collaboration and synergy from various stakeholders, played a big role in addressing the problems. Data validation conducted by BRI plays a big role in overcoming double data. RTG design from the Kementerian PUPR makes it easy for people to plan and rebuild their homes. TNI is present to assist technically in accelerating development. Facilitators assist the community in planning, applying for funds, implementation, and reporting. These efforts make the problems faced when the implementation of innovations in disaster management are resolved. These efforts, making breakthroughs in disaster management can be carried out. Each stakeholder has an equally important role in synergizing and collaborating with all stakeholders to support the achievement of disaster management objectives.
\end{abstract}

\title{
Keywords
}

earthquake; rehabilitation; reconstruction; stakeholder; earthquake resistant houses 


\section{Pendahuluan}

Indonesia, secara historiografi merupakan negara yang rawan terhadap terjadinya bencana alam seperti gunung meletus, gempa bumi, tsunami, banjir, angin topan dan tanah longsor. Hal ini tidak terlepas dari posisi Indonesia yang terletak di antara pertemuan Lempeng Eurasia, Lempeng Indo-Australia, dan lempeng Pasifik yang menjadikan Indonesia rentan mengalami berbagai bencana geologis, termasuk gempa bumi (Kurniawan dkk., 2016, hlm. 107). Bencana tersebut dapat menyebabkan timbulnya korban jiwa manusia, kerusakan lingkungan, kerugian harta benda, dan dampak psikologis yang dalam keadaan tertentu dapat menghambat pembangunan nasional. Salah satu bencana besar tersebut ialah terjadinya gempa bumi di Provinsi NTB tahun 2018.

Bencana gempa bumi Nusa Tenggara Barat (NTB) terjadi beberapa kali dalam waktu yang berdekatan. Pertama, pada 29 Juli 2018, pukul 06.47 WITA dengan kekuatan 6,4 skala Richter. Kedua, pada 5 Agustus 2018 tepat pukul 18:46 WITA dengan kekuatan mencapai 7,0 skala Richter. Ketiga, 9 Agustus 2018 Pukul 12;25 WITA gempa susulan dengan kekuatan 6,2 skala Richter. Keempat, pada hari Minggu tanggal 19 Agustus 2018 pukul 22:56:27 WITA dengan magnitudo 6,9 skala Richter (Pusdatinmas BNPB, 2018).

Gempa NTB menyebabkan 564 jiwa meninggal, 1.469 jiwa luka-luka, 73.897 jiwa pengungsi. Kejadian gempa bumi ini juga menyebabkan setidaknya rumah rusak berat 75.138 unit, rumah rusak sedang 33.075 unit, dan rumah rusak ringan 108.306 unit. Fasilitas umum dan fasilitas sosial yang terdampak dari gempa ini juga meliputi 855 sekolah, 12 pasar, 61 rumah sakit dan puskesmas/pustu, dan 389 fasilitas ibadah dan fasilitas lainnya. Selain mengakibatkan kerugian dan sifatnya fisik, bencana gempa juga berdampak pada sektor ekonomi, yaitu terpukulnya pariwisata NTB. Hal ini disebabkan karena wilayah NTB khususnya Pulau Lombok sebagian besar pendapatannya dari pariwisata dan kejadian tersebut nyaris mematikan seluruh aktivitas pariwisata di Pulau Lombok termasuk Gili Air, Gili Meno, dan Gili Trawangan. Diperkirakan potensi kerugian yang dialami oleh Pariwisata NTB yang diakibatkan oleh serangkaian gempa bumi mencapai 100 juta dolar AS (Nukman, 2018).

Melihat masifnya dampak yang ditimbulkan bencana gempa bumi di NTB pada 2018, dibutuhkan upaya penanggulangan bencana yang sifatnya segera dan holistik. Kajian yang dilakukan oleh (Kaku, 2019) menunjukkan bahwa penggunaan satelit pengindraan jauh sebagai alat pendukung utama untuk manajemen bencana berhasil karena dalam penerapannya dilakukan secara holistik. Upaya holistik di sini tidak hanya dari kecanggihan teknologi yang digunakan tetapi juga tahapan hingga stakeholder yang terlibat. Di Indonesia, upaya penanggulangan bencana dilakukan melalui tiga tahap, yaitu: prabencana, saat tanggap darurat, dan pascabencana (Undang-Undang Republik Indonesia Nomor 24 Tahun 2007 tentang Penanggulangan Bencana, 2007).
Tahap prabencana dilakukan untuk mengurangi risiko bencana dan berbagai upaya pencegahan. Pada tahap tanggap darurat, kegiatan yang dilakukan yaitu: pengkajian, penentuan status keadaan darurat bencana, penyelamatan dan evakuasi masyarakat pemenuhan kebutuhan dasar, perlindungan terhadap kelompok rentan, dan pemulihan dengan segera prasarana dan sarana vital. Sementara itu, dalam tahap pascabencana, penyelenggaraan penanggulangan bencana dilakukan dalam bentuk rehabilitasi dan rekonstruksi (Undang-Undang Republik Indonesia Nomor 24 Tahun 2007 tentang Penanggulangan Bencana, 2007).

Tiga tahap penanggulangan bencana dilakukan secara bertahap dalam rentang waktu yang berbeda. Namun demikian, dalam penanggulangan bencana gempa bumi yang terjadi di NTB tahun 2018 berbeda dari penanggulangan bencana pada umumnya. Pemerintah berupaya melakukan terobosan dengan melakukan tahap dua dan tiga dilakukan secara bersamaan. Melalui Instruksi Presiden (Inpres) Nomor 5 Tahun 2018 tentang Percepatan Rehabilitasi dan Rekonstruksi Pasca Bencana Gempa Bumi di Kabupaten Lombok Barat, Lombok Utara, Lombok Tengah, Lombok Timur, Kota Mataram, dan wilayah terdampak di Provinsi NTB, pemerintah melakukan tahapan rehabilitasi dan rekonstruksi dilakukan bersamaan dengan tahap tanggap darurat. Terobosan ini merupakan sesuatu yang baru dalam penanggulangan bencana apalagi dengan konteks bencana yang memiliki tingkat kerusakan dan korban jiwa dalam jumlah sangat besar.

Di awal pelaksanaan terobosan penanggulangan bencana, tidak berjalan lancar. Banyak masalah yang muncul, seperti: data ganda, petugas lapangan tidak memiliki pemahaman dan standar yang sama untuk menentukan tingkat kerusakan rumah; data rumah rusak yang diajukan untuk diperbaiki pemerintah daerah tidak sesuai realitas; dana yang sudah dicairkan oleh pemerintah pusat ke pemerintah daerah tidak terserap dengan baik, dan target pembangunan rumah meleset jauh.

Meskipun di awal kegiatan penanggulangan bencana terkendala dan secara waktu mundur hingga 2 tahun tetapi, pembangunan RTG mampu mencapai target. Hingga Februari 2021 lebih dari 95\% untuk seluruh wilayah (Kepala BPBD Provinsi NTB, 2021). Tidak hanya itu, RTG benarbenar dimanfaatkan oleh masyarakat. Kondisi ini mengindikasikan bahwa upaya penanggulangan bencana yang dilakukan Pemerintah di NTB sesuai dengan kebutuhan masyarakat. Hal ini tidak terlepas dari peran aktif berbagai stakebolder terkait.

Penanggulangan pascabencana merupakan tanggung jawab utama dari pemerintah, baik di tingkat pusat maupun daerah. Namun demikian, dalam praktiknya, keterlibatan aktif dari pihak lain seperti pihak swasta, lembaga non-pemerintah dan masyarakat menjadi sangat penting. Hal ini seperti yang tercantum dalam Undang-Undang Nomor 24 Tahun 2007 bahwa dalam penanggulangan bencana, dibutuhkan adanya 
kolaborasi berbagai stakeholder. Untuk memahami bagaimana peran stakeholder tersebut digunakan teori Pentahelix.

Teori Pentahelix yang dikemukakan oleh Mohr dan Spekman (1994) dalam Rachim dkk. (2020, hlm. 21) mengemukakan bahwa ada lima kelompok stakeholder di antaranya: pemerintah, dunia usaha, perguruan tinggi, organisasi non-pemerintah/lembaga swadaya masyarakat, dan media massa. Banyak kajian sebelumnya menunjukkan bahwa keterlibatan berbagai stakeholder memiliki peran krusial dalam penanggulangan pascabencana. Kajian yang dilakukan oleh Yumantoko (2019, hlm. 25) menunjukkan bahwa kolaborasi dari berbagai pihak dalam penanggulangan bencana dapat mengurangi dampak buruk gempa bumi yang terjadi di Pulau Lombok. Demikian juga dengan kajian yang dilakukan oleh Rianto (2015) bahwa adanya koordinasi yang baik antara BPBD dengan stakeholder lain membuat penanggulangan bencana di Jawa Timur berjalan dengan efektif. Meskipun stakeholder yang terlibat banyak tidak serta merta menjamin penanggulangan bencana berhasil. Hal ini tidak terlepas dari faktor penting lainnya yaitu bagaimana sinergi dari berbagai stakebolder yang ada. Kajian yang dilakukan Apriyani dkk. (2020, hlm. 186) menunjukkan bahwa meskipun di dalam penanggulangan bencana di Selat Sunda, Lampung sudah melibatkan pihak swasta tetapi tetap tidak berhasil dan menimbulkan masalah baru. Tidak ada kerja sama di antara pemerintah dan swasta menjadi penyebabnya.

Berbagai kajian di atas semakin menguatkan bahwa tidak cukup hanya melihat banyaknya stakeholder yang terlibat. Hal penting lainnya yaitu bagaimana kolaborasi dan sinergi yang dilakukan dalam penanggulangan bencana. Tidak hanya itu, kajian sebelumnya juga menunjukkan bencana dengan jumlah korban yang relatif lebih sedikit. Padahal, gempa bumi dengan intensitas sering dan jumlah korban yang besar memiliki tantangan yang unik dibandingkan bencana alam lain. Dalam penelitian sebelumnya dinamika kolaborasi yang dilakukan stakebolder terkait dalam penanggulangan bencana besar belum banyak dilakukan. Oleh karena itu, dalam tulisan ini dikaji secara mendalam mengenai peran stakeholder dan kolaborasi yang dilakukan oleh para stakebolder dalam penanganan bencana gempa bumi di NTB tahun 2018. Tulisan ini bertujuan untuk mendeskripsikan kolaborasi berbagai stakebolder yang terlibat sehingga penanggulangan bencana NTB berhasil. Kajian ini berangkat dari dua pertanyaan besar: 1) bagaimana inovasi penanggulangan bencana NTB pada 2018 dan permasalahannya, dan 2) bagaimana kolaborasi yang dilakukan para stakebolder.

\section{Metode}

Kajian ini dilakukan berdasarkan studi dokumen. Studi dokumen dilakukan dengan tujuan mengkaji informasi dan data yang telah tersedia (Bryman, 2008, hlm. 98). Selain itu, studi dokumen dilakukan untuk mengintegrasikan dan membuat ringkasan dari apa yang sudah diketahui dari sebuah topik penelitian sehingga dapat menstimulasi ide baru dari penelitian (Neuman, 2006, hlm. 126). Studi dokumen yang dilakukan dalam kajian ini berupa data-data yang dimiliki pemerintah pusat dan pemerintah daerah serta literatur review dari artikel ilmiah terkait.

Data yang dikumpulkan berupa data sekunder yang dilakukan secara sistematis pada bulan November 2020 hingga April 2021. Data tersebut bersumber dari dua jenis. Pertama, data mengenai situasi bencana yang terjadi di NTB tahun 2018 baik yang dimiliki oleh Kemenko PMK, BNPB, maupun Badan Penanggulangan Bencana Daerah tingkat provinsi/ kabupaten/kota. Kedua, literatur dari artikel jurnal, prosiding, penelitian, dan buku mengenai penanggulangan kebencanaan dan peran dari stakeholder dalam penanggulangan kebencanaan, baik yang terjadi di NTB maupun bencana di tempat lainnya.

Data yang diperoleh dianalisis secara berjenjang dan sistematis dengan memberikan makna yang signifikan terkait siapa saja stakebolder yang terlibat dan bagaimana peran mereka dalam tahapan penanggulangan bencana gempa bumi di NTB. Hasil kajian disajikan secara deskriptif, yaitu dengan memberikan gambaran secara spesifik mengenai siapa saja yang terlibat dalam penanggulangan bencana, peran setiap stakebolder yang terlibat, dan bagaimana kolaborasi yang dilakukan oleh stakeholder pada proses penanggulangan bencana ini. Data dianalisis dengan teori dan berbagai kajian sebelumnya sehingga diperoleh gambaran yang lebih jelas tentang bagaimana kolaborasi para stakebolder dalam menanggulangi bencana gempa bumi.

\section{Hasil dan Pembahasan}

\subsection{Inovasi Penanggulangan Pascabencana Gempa Bumi NTB dan Permasalahan yang Dihadapi}

Merespons kejadian bencana Gempa Bumi NTB, Pemerintah telah bergerak cepat mengambil tindakan dan merumuskan kebijakan di tingkat Pemerintah Pusat hingga Pemerintah Daerah baik Pemerintah Daerah tingkat Provinsi hingga Kabupaten/Kota. Langkah cepat ini diawali dengan adanya ketentuan masa tanggap darurat yang dikeluarkan oleh Gubernur NTB yang berlaku mulai dari 29 Juli 2018 hingga 4 Agustus 2018. Masa tanggap darurat kemudian diperpanjang menjadi 11 Agustus 2018 dan diperpanjang lagi hingga 25 Agustus 2019. Setelah masa tanggap darurat berakhir, Gubernur NTB segera menerbitkan Surat Keputusan Gubernur Nomor 360-696 Tahun 2018 tentang Status Transisi Darurat ke Pemulihan dan Perbaikan Darurat Akibat Bencana Alam Gempa Bumi di Pulau Lombok dan Sumbawa selama 23 hari mulai tanggal 26 Agustus 2018 hingga 17 September 2018. Masa transisi darurat ke pemulihan ini kemudian diperpanjang hingga 12 April 2019 dan kembali diperpanjang hingga 30 April 2021. Penetapan masa tanggap darurat bertujuan untuk memudahkan akses dalam pengadaan logistik. Penanganan dapat cepat dilakukan karena adanya kemudahan akses dalam administrasi, penggunaan anggaran, pengerahan personil, logistik dan peralatan (Mohammad, 2018). 
Dalam hal pemulihan pasca bencana gempa bumi di NTB, upaya-upaya rehabilitasi dan rekonstruksi terdiri dari: Sektor Sosial, Ekonomi, Infrastruktur, Pemukiman serta Lintas Sektor (Bakti \& Nurmandi, 2020, hlm. 140). Masa rehabilitasi dan rekonstruksi dilaksanakan pada saat status kebencanaan masih dalam konteks penanganan tanggap darurat bencana.

Rehabilitasi dan rekonstruksi sarana dan prasarana sosial dan umum dilaksanakan secara simultan bersamaan dengan pelaksanaan tanggap darurat. Kondisi ini yang membedakan dengan penanganan pascabencana di wilayah lain, misalnya bencana tsunami Mentawai tahun 2010. Masa tanggap darurat dilakukan tahun 2010 (Sinaga, 2013, hlm. 24). Sementara itu, berdasarkan Rencana Aksi Rehabilitasi dan Rekonstruksi Pasca Tsunami Mentawai, masa rehabilitasi dan rekonstruksi dilakukan satu tahun kemudian, yaitu tahun 2011 dan dilanjutkan pada tahun 2012 (Sinaga, 2013, hlm. 25-26). Meskipun demikian, hingga tahun 2012 masa rehabilitasi dan rekonstruksi masih belum dimulai (Sinaga, 2013, hlm. 28).

Penggabungan masa rehabilitasi dan rekonstruksi dengan masa tanggap darurat dikarenakan tipikal bencana gempa bumi NTB yang berbeda dengan kejadian gempa bumi yang biasanya terjadi. Kejadian bencana gempa bumi biasanya terjadi dengan sekali guncangan gempa besar dan diikuti dengan guncangan-guncangan gempa kecil. Kejadian gempa NTB tahun 2018 terjadi dengan empat kali guncangan besar di atas 6 skala Richter dengan rentang waktu yang berdekatan. Oleh karena itu, dibutuhkan upaya cepat untuk mengatasinya, yaitu melakukan rehabilitasi dan rekonstruksi yang dijalankan beriringan dengan tanggap darurat.

Presiden Joko Widodo dalam kunjungan kerjanya ke lokasi terdampak bencana gempa bumi NTB pada tanggal 30 Juli 2018, memberikan arahan penting untuk percepatan pembangunan. Salah satunya yaitu percepatan pembangunan kembali rumah rusak melalui bantuan stimulan yang bersumber dari Dana Siap Pakai (DSP) BNPB sebesar Rp50.000.000 (untuk rumah dengan kategori rusak berat) (Sekretaris Kabinet Republik Indonesia, 2018). Arahan tersebut dikeluarkan pada saat kejadian gempa bumi NTB yang pertama pada tanggal 29 Juli 2018 di mana verifikasi awal jumlah korban dan kerusakan bangunan masih relatif kecil yaitu 16 orang meninggal dunia dan perkiraan bangunan rusak sebanyak 1.000 unit (Zulfakriza, 2018). Setelah terjadi beberapa gempa susulan jumlah korban yang meninggal dunia mencapai 564 jiwa dan 75.138 unit rumah yang mengalami kerusakan berat, rumah rusak sedang 33.075 unit dan rumah rusak ringan 108.306 unit.

Dalam mengejawantahkan arahan Presiden tersebut, diterbitkan Instruksi Presiden Nomor 5 Tahun 2018 yang berisi:

1. Rehabilitasi dan rekonstruksi sarana berupa fasilitas pendidikan, fasilitas kesehatan, fasilitas agama dan fasilitas penunjang perekonomian agar aktivitas berfungsi kembali. Rehabilitasi dan rekonstruksi diselesaikan paling lambat pada akhir bulan Desember 2018 dan sarana lain diselesaikan paling lambat Desember 2019.

2. Pembangunan perumahan tahan gempa bagi masyarakat terdampak bencana gempa bumi dengan skema swakelola oleh masyarakat.

Dari Instruksi Presiden Nomor 5 Tahun 2018 ini jelas bahwa yang menjadi prioritas utama rekonstruksi yaitu pembangunan perumahan terdampak gempa dengan sistem swakelola oleh masyarakat. Hal ini sesuai dengan definisi dari pemulihan pasca bencana yang disampaikan oleh (Coppola, 2006) bahwa pemulihan pasca bencana dilakukan oleh negara, masyarakat, keluarga hingga individu untuk memperbaiki, merekonstruksi atau mendapatkan kembali apa yang telah hilang karena bencana. Dalam hal ini, sesuatu yang hilang berupa rumah dengan tingkat kerusakan yang beragam. Hal penting lainnya yaitu adanya pelibatan aktif dari masyarakat, keluarga hingga individu dalam prosesnya.

Dilihat dari segi waktu rehabilitasi dan rekonstruksi, di dalam Instruksi Presiden Nomor 5 Tahun 2018 disebutkan 1 tahun dari sejak ditetapkan, dengan kata lain Desember 2019 semua pembangunan RTG sudah selesai. Namun demikian, hingga Desember 2020 realisasi pembangunan masih berada di kisaran $90 \%$. Dana yang diberikan pemerintah pusat sesuai dengan pengajuan dari pemerintah pusat, tetapi masih belum terserap dan pemerintah daerah terus melakukan perbaikanperbaikan pengajuan dana. Kondisi ini tidak terlepas dari adanya data. Jika ditelisik lebih lanjut, permasalahan data ganda muncul karena ketidaksiapan pemerintah daerah sebagai pelaksana kebijakan. Mengingat waktu yang disediakan sangat terbatas dengan kondisi jumlah kerusakan dan korban jiwa yang sangat banyak membuat pemerintah harus bergerak cepat. Oleh karena itu, tidak ada proses validasi data. Kondisi ini yang menyebabkan terjadinya data ganda.

Permasalahan data ganda tidak terlepas dari serangkaian tindakan yang seharusnya dilakukan pemerintah tapi tidak dilakukan secara optimal. Coppola (2006) menyebutkan sejumlah tindakan yang harus dilakukan pada periode pemulihan yaitu komunikasi dengan masyarakat juga pengkajian kerusakan dan kebutuhan. Selain waktu yang sangat cepat, ketidaksiapan petugas melakukan akselerasi upaya rekonstruksi juga ikut andil dalam permasalahan ini.

Petugas lapangan tidak memiliki pemahaman yang sama mengenai definisi dan kriteria penentuan tingkat kerusakan rumah. Panduan untuk menentukan tingkat kerusakan baru muncul setelah data sebagian data dari pemerintah daerah masuk ke pemerintah pusat. Dampaknya, ada ketidaksesuaian antara data yang diajukan dengan realitas yang ada.

Tidak ada kesamaan standar penentuan RTG dan tidak ada validasi data berkontribusi terhadap terhambatnya proses rehabilitasi dan rekonstruksi. Tidak hanya itu, tidak adanya gambaran dari masyarakat bagaimana merancang dan membuat RTG, membuat dana yang ada tidak terserap maksimal. Masyarakat mengalami kebingungan bagaimana membuat RTG. Permasalahan lainnya yang juga muncul yaitu 
terbatasnya sumber daya manusia untuk membangun rumah tersebut. Berbagai permasalahan ini yang menyebabkan proses rehabilitasi dan rekonstruksi pasca gempa bumi tidak berjalan lancar dan mundur hingga dua tahun. Padahal di sisi lain, stakebolder yang terlibat dalam penanggulangan bencana ini sangat banyak seperti yang tercantum dalam Instruksi Presiden Nomor 5 Tahun 2018.

Menindaklanjuti permasalahan tersebut, pemerintah mengeluarkan Instruksi Presiden terbaru, Instruksi Presiden Nomor 7 Tahun 2020 untuk mendorong penuntasan penyelesaian perbaikan, dan pembangunan kembali rumah masyarakat pada wilayah terdampak bencana gempa bumi di Provinsi NTB. Inpres ini mengatur dan memberikan tugas khusus kepada Menteri Koordinator Bidang Pembangunan Manusia dan Kebudayaan untuk koordinasi Percepatan Pelaksanaan Rehabilitasi dan Rekonstruksi Pasca Bencana Gempa Bumi.

Instruksi Presiden Nomor 7 Tahun 2020 memerintahkan tiga menteri (Menko PMK, Mendagri, Menkeu), Panglima TNI, Kapolri, BNPB, BPKP, Gubernur NTB, 5 Bupati, dan 1 Walikota untuk segera melaksanakan percepatan penyelesaian perbaikan dan pembangunan kembali rumah masyarakat pada wilayah terdampak bencana gempa bumi di Provinsi NTB dengan menggunakan Dana Siap Pakai (DSP) yang diselesaikan paling lambat bulan Desember 2020. Upaya percepatan ini dilakukan melalui percepatan pembangunan Hunian Tetap/RTG (RTG), penyaluran dana bantuan stimulan, pembangunan fasilitas umum dan fasilitas sosial. Dalam penanganan Pasca Gempa Bumi di NTB ini pemerintah telah menganggarkan Dana Siap Pakai sebesar Rp5,11 triliun.

Dana Siap Pakai disalurkan dalam bentuk uang kepada penerima manfaat. Penyaluran dalam bentuk uang memberikan manfaat lebih kepada masyarakat karena masyarakat dapat lebih fleksibel menggunakan bantuan ini sesuai dengan kebutuhannya. Hal ini seperti hasil kajian yang dilakukan oleh Habibullah dan Pudjianto (2014, hlm. 31) bahwa mekanisme bantuan berupa uang yang disalurkan melalui rekening kelompok relatif lebih baik dibanding dengan penyaluran bantuan berupa barang. Pemberian bantuan dalam bentuk uang memungkinkan masyarakat untuk bisa membeli kebutuhan bangunan yang diperlukan.

Adapun mekanisme penyaluran bantuan perbaikan rumah mengacu pada Petunjuk Pelaksanaan Bantuan Stimulan Perbaikan Rumah Korban Bencana Gempa Bumi di Provinsi NTB (Badan Nasional Penanggulangan Bencana, 2018, hlm. 33), yaitu meliputi:

1. Persiapan kelengkapan administrasi dan penyusunan rencana anggaran bantuan perbaikan rumah korban bencana

2. PPK BPBD Kabupaten/Kota menilai kelengkapan dokumen pencairan dana dan selanjutnya menerbitkan surat rekomendasi kepada Bank Penyalur untuk disalurkan ke rekening masyarakat penerima bantuan stimulan.
3. Pencairan bantuan stimulan perbaikan rumah korban bencana

4. Pelaksanaan konstruksi

5. Penyelesaian konstruksi

Pada tahap dua, sebelum PPK BPBD Kabupaten/Kota menerbitkan surat rekomendasi, ada sejumlah langkah yang harus dipenuhi.

1. POKMAS membuat dokumen teknis perbaikan rumah yang didampingi oleh fasilitator.

2. POKMAS menyiapkan sejumlah persyaratan administrasi: berita acara pembentukan POKMAS; surat keputusan lurah/kepala desa pembentukan POKMAS; identitas anggota POKMAS; surat kepemilikan tanah atau hak guna atas tanah; foto kondisi fisik 0\%; dan gambar rencana rumah.

3. Masing-masing anggota POKMAS membuat pernyataan kesanggupan menyelesaikan perbaikan rumah korban bencana dari dana DSP yang diterima bermeterai.

4. PPK BPBD Kab/Kota memerintahkan BRI untuk melakukan pemindahbukuan dari rekening masyarakat ke rekening POKMAS, dilakukan secara bertahap sesuai dengan progres pekerjaan.

5. PPK BPBD Kab/Kota bersama POKMAS menandatangani SPP perbaikan rumah korban bencana, yang memuat jumlah bantuan stimulan perbaikan rumah korban bencana, nama penerima dan alamatnya, tahapan pembayaran, hak dan kewajiban serta sanksi masing-masing pihak.

Setelah satu tahun berjalan, diketahui bahwa realisasi pembangunan RTG masih jauh dari target awal. Pembangunan RTG kategori rusak berat hanya mencapai 56\%, rusak sedang 57\% dan rusak ringan 66\% (lihat Tabel 1). Padahal, di saat yang bersamaan dana yang disalurkan BNPB mencapai Rp5,07 triliun. Dari total dana yang telah dicairkan BNPN, ada Rp5,31 triliun yang sudah masuk ke rekening masyarakat. Artinya ada sekitar Rp0,39 triliun yang belum terserap. Dari Rp5,31 triliun dana yang sudah masuk rekening masyarakat, masih ada Rp229 miliar yang belum masuk ke rekening Pokmas.

Tabel 1. Realisasi Pembangunan RTG Hingga Januari 2020

\begin{tabular}{lccc}
\hline Kategori & Target RTG & $\begin{array}{c}\text { Jumlah } \\
\text { RTG } \\
\text { Selesai } \\
\text { Terbangu } \\
\mathbf{n}\end{array}$ & Persentase \\
\hline Rusak Berat & 74.734 & 41.752 & $56 \%$ \\
\hline Rusak Sedang & 36.300 & 20.850 & $57 \%$ \\
\hline Rusak Ringan & 115.256 & 75.532 & $66 \%$ \\
\hline
\end{tabular}

Sumber: $B N P B(2020)$ 
Tabel 2. Progres Pembangunan Fisik Tahap 1

\begin{tabular}{clc}
\hline No. & \multicolumn{1}{c}{ Kota/Kabupaten } & Progres \\
\hline 1 & Kota Mataram & $100 \%$ \\
\hline 2 & Kabupaten Lombok Barat & $99,10 \%$ \\
\hline 3 & Kabupaten Lombok Tengah & $97,45 \%$ \\
\hline 4 & Kabupaten Lombok Timur & $97,99 \%$ \\
\hline 5 & Kabupaten Sumbawa Barat & $99,25 \%$ \\
\hline 6 & Kabupaten Sumbawa & $100 \%$ \\
\hline Sumber: Kepala BPBD Provinsi NTB (2021)
\end{tabular}

Sumber: Kepala BPBD Provinsi NTB (2021)

Kondisi ini menggambarkan bahwa di awal pelaksanaan inovasi penanggulangan bencana hingga dua tahun berjalan, tidak dapat berjalan dengan lancar. Akan tetapi, pada Februari 2021 diketahui bahwa pembangunan fisik RTG di 6 lokasi mencapai $97 \%$ dan dua wilayah di antaranya, Kota Mataram dan Kabupaten Sumbawa mencapai $100 \%$. Pembentukan POKMAS juga mencapai 214.333 (99,52\%).

Data pada Tabel 2 menunjukkan bahwa meskipun secara waktu penanggulangan bencana mundur cukup lama, tetapi RTG yang terbangun dan dihuni masyarakat lebih dari $95 \%$. Kondisi ini mengindikasikan bahwa terobosan yang dilakukan pemerintah dengan menggabungkan tahap tanggap darurat dan pascabencana cukup berhasil. Dengan kata lain, permasalahan yang ditemui di awal pelaksanaan inovasi penanggulangan kebijakan telah teratasi. Keberhasilan ini tidak terlepas dari adanya koordinasi, kolaborasi dan sinergitas dari berbagai stakeholder terkait.

\subsection{Stakeholder yang Terlibat dalam Penanggulangan Pascabencana Gempa Bumi NTB}

Stakeholder memiliki dampak positif pada praktik pemulihan bencana. Dengan meningkatkan atribut kekuatan, legitimasi dan urgensi dari stakeholder, pelaksanaan tanggap darurat dan pemulihan penanggulangan bencana lebih efektif (Mojtahedi \& Oo, 2017, hlm. 35). Di dalam Undang-Undang Nomor 24 Tahun 2007 disebutkan bahwa stakeholder yang berperan ialah pemerintah pusat, pemerintah daerah, BNPB, lembaga usaha, dan lembaga internasional. Kajian yang dilakukan oleh Kaku (2019) bahwa keberhasilan manajemen bencana secara holistik, sumber daya manusia yang terlibat berperan sangat krusial. Dikatakan bahwa penggunaan teknologi dalam penanggulangan bencana berjalan efektif karena adanya kerja sama dari berbagai stakeholder.

Stakeholder yang terlibat secara aktif dalam proses penanggulangan bencana gempa bumi di NTB, terdiri dari multisektor: pemerintah, dunia usaha, dan masyarakat. Dari sektor pemerintah, mengacu pada Instruksi Presiden Nomor 7 Tahun 2020, pemerintah yang terlibat, yaitu Kemenko PMK, Kementerian Dalam Negeri, Kementerian Keuangan, TNI, POLRI, BNPB, BPKP, Pemerintah Daerah Provinsi NTB,
Pemerintah Daerah Kabupaten/Kota melalui BPBD. Sementara itu, dari Inpres Nomor 5 Tahun 2018, tambahan stakeholder yang terlibat, yaitu Kementerian PUPR. Dari pihak dunia usaha, yaitu Bank Rakyat Indonesia (BRI) dan masyarakat yang terbentuk dalam Pokmas. Dalam tulisan ini, akan diulas secara lebih mendalam yaitu peran dari beberapa stakeholder yang memiliki peran krusial dalam mengatasi permasalahan yang muncul, di antaranya: Kementerian PUPR, BRI, TNI, Fasilitator, POKMAS.

\subsubsection{Kementerian PUPR}

Dalam penanggulangan bencana gempa bumi di NTB, Kementerian PUPR memiliki peran krusial berupa penyiapan desain RTG. Desain RTG terdiri dari rumah instan sederhana sehat (RISHA), rumah instan struktur baja (RISBA), rumah instan kayu (RIKA), dan rumah instan konvensional (RIKO). Beberapa desain rumah diberikan kepada masyarakat sebagai alternatif model RTG yang disesuaikan dengan kondisi dan kebutuhan masyarakat. Desain RTG ini berkontribusi positif terhadap pembangunan hunian tetap/RTG karena memudahkan masyarakat dalam mengajukan pencairan dana. Seperti yang disebutkan sebelumnya, bahwa untuk mencairkan dana bantuan, dalam pengajuan yang dilakukan masyarakat melalui Pokmas harus mencantumkan desain RTG yang akan dibangun. Sebelumnya, masyarakat mengalami kesulitan melengkapi persyaratan ini karena masyarakat tidak mengetahuinya. Dengan adanya beberapa pilihan desain RTG, masyarakat menjadi lebih mudah membuatnya.

Peran berikutnya yang dilakukan oleh Kementerian PUPR yaitu menyiapkan fasilitator yang bertugas mendampingi masyarakat untuk membentuk Pokmas, bekerja sama dengan aplikator pembangunan rumah dan membantu mengurus administrasi yang dibutuhkan. Ini merupakan bentuk dari pelaksanaan tugas Kementerian PUPR dalam melakukan pendampingan dan pengawasan pembuatan RTG. Melalui fasilitator, membantu masyarakat dalam memilih desain RTG dan menjalin kerja sama dengan aplikator. Aplikator merupakan kontraktor yang berperan membangun rumah bagi masyarakat terdampak bencana.

\subsubsection{Bank Rakyat Indonesia}

Dari dunia usaha, stakeholder yang terlibat secara langsung yaitu Bank Rakyat Indonesia (BRI). Sebagai bagian dari unit usaha BUMN yang bergerak di perbankan, BRI memiliki peran yang sangat besar. Di dalam Instruksi Presiden Nomor 5 Tahun 2018 disebutkan bahwa unit BUMN berperan dalam mendukung percepatan rehabilitasi dan rekonstruksi pascabencana gempa bumi. BRI berperan dalam menampung dana bantuan perumahan bagi masyarakat terdampak. Dana dari BNPB yang merupakan kas negara masuk ke BRI dan BRI yang bertugas melakukan pencairan. Sebelum dana dicairkan, ada sejumlah persyaratan dan kewajiban yang harus dipenuhi masyarakat. Persyaratan pertama yaitu masyarakat harus memiliki rekening atas nama sendiri di BRI. 
Kedua, masyarakat harus menyetor sejumlah persyaratan administratif. Kelengkapan administratif pada dasarnya berfungsi untuk melakukan validasi data penerima bantuan. Dengan demikian, data ganda dari penerima bantuan dapat diminimalisir. Dalam hal ini, kelengkapan administratif yang disyaratkan oleh BRI yaitu mencantumkan nomor induk kependudukan dengan melampirkan KTP dan KK. Upaya yang dilakukan BRI efektif untuk memvalidasi data calon penerima bantuan sehingga dapat dipastikan bahwa 1 rumah tangga hanya mendapatkan 1 jenis bantuan pembangunan RTG. Ketika ada koordinasi dan kerja sama dengan pihak swasta, pelaksanaan penanggulangan menjadi semakin cepat karena pihak swasta dapat mengakselerasi dan meningkatkan dalam merespons saat terjadi bencana dan memulihkannya (Busch \& Givens, 2013, hlm. 19).

Kondisi ini menunjukkan bahwa BRI sebagai sektor usaha, tidak hanya berperan dalam pencairan dana tetapi sebagai bagian dari proses akurasi penerima bantuan. Hal ini seperti yang dikemukakan oleh Busch dan Givens (2013, hlm. 19) serta Hunt dan Eburn (2018, hlm. 482) bahwa dunia usaha memiliki peran besar dalam membantu pemerintah menanggulangi bencana yang terjadi di suatu wilayah. Namun demikian, kontribusi dari dunia usaha dapat berjalan ketika pemerintah melakukan koordinasi yang baik dengan dunia usaha. Kajian sebelumnya menemukan bahwa keseriusan dunia usaha menjadi kurang membantu masyarakat karena pemerintah tidak merespons dengan baik kontribusi yang dilakukan oleh dunia usaha (Apriyani dkk., 2020, hlm. 186).

\subsubsection{Tentara Nasional Indonesia (TNI)}

Peran besar berikutnya yaitu dari TNI. Pada saat terjadi bencana gempa bumi NTB, Komando Resort Militer (Korem) 162/Wira Bhakti bertugas menjadi komandan tim pos komando (Dantim Posko) tangap darurat bencana alam Gempa Bumi di Pulau Lombok NTB melalui SK Gubernur NTB Nomor 360-611 Tahun 2018 tanggal 30 Juli 2018. Pada fase tanggap darurat, TNI menjadi garda terdepan dalam memberikan pertolongan pertama dan penyelamatan korban (Hediarto dkk., 2016, hlm. 328). Selain menyelamatkan korban gempa, TNI juga berperan besar pada tahap rehabilitasi dan rekonstruksi.

TNI telah membangun sebanyak 226.303 unit RTG diperuntukkan bagi tempat tinggal masyarakat yang terdampak gempa dan membantu pemulihan perekonomian masyarakat. Pada fase rehabilitasi dan rekonstruksi, TNI menjadi garda terdepan dalam membantu warga memenuhi kebutuhan dasarnya. Hal yang serupa juga dilakukan oleh TNI dalam penanggulangan bencana di Provinsi Lampung. Keterlibatan TNI dalam penanggulangan bencana mulai dari tahap pra bencana, tanggap darurat, hingga pascabencana (Widyaningrum dkk., 2020, hlm. 46).

\subsubsection{Fasilitator}

Fasilitator memiliki peran krusial karena mereka yang berinteraksi dengan masyarakat secara langsung, membantu masyarakat dalam membangun rumah hunian tetap, menyiapkan kelengkapan administrasi sebagai persyaratan pencairan dana bantuan, hingga pembuatan laporan. Hal ini seperti yang disampaikan oleh Pelaksana Tugas Deputi Bidang Koordinasi Dampak Bencana dan Kerawanan Sosial Kementerian Koordinator Pembangunan Manusia dan Kebudayaan, Panglima Komando Satuan Gugus Tugas Gabungan Terpadu (Pangkogasgabpad), dan Deputi 3 Rehabilitasi dan Rekonstruksi BNPB (BNPB) (Syambudi, 2018).

Kehadiran fasilitator membuat masyarakat menjadi lebih paham dengan pembangunan RTG yang sesuai standar. Para fasilitator di lapangan bekerja dengan melakukan pendampingan ke masyarakat, menjelaskan berbagai desain RTG yang sudah dibuat oleh Kementerian Pekerjaan Umum dan Perumahan Rakyat, menggali kebutuhan dan kondisi yang sekarang dihadapi masyarakat, serta memilih desain RTG yang sesuai dengan kondisi masyarakat. Hal ini seperti kajian sebelumnya yang menyatakan bahwa fasilitator memiliki peran krusial sebagai jembatan antara pemerintah dan masyarakat. Fasilitator berperan dalam menyampaikan informasi dari pemerintah kepada masyarakat (Sagala dkk., 2013, hlm. 221).

Kontribusi positif lainnya terkait dengan proses pencairan dana bantuan. Untuk mencairkan dana bantuan, dibutuhkan sejumlah persyaratan administratif yang harus dilengkapi termasuk persetujuan dari fasilitator. Adanya pendampingan yang dilakukan oleh para fasilitator membuat masyarakat menjadi lebih mudah melakukannya sehingga pencairan dana menjadi lancar. Kondisi ini berdampak positif terhadap pembangunan RTG secara keseluruhan yang menjadi lebih cepat dan dapat berjalan sesuai target. Kondisi yang serupa juga ditemui dalam rekonstruksi perumahan pascabencana gempa bumi Jawa Barat 2009 (Sagala dkk., 2013, hlm. 222).

Hal ini juga yang dikemukakan oleh Wali Kota Mataram dalam memberikan penghargaan kepada para fasilitator. Keberhasilan Kota Mataram dalam membangun RTG sesuai target mencapai $100 \%$ karena kerja keras para fasilitator dalam membantu masyarakat dalam proses rehabilitasi rumah yang terkena dampak (Pemerintah Daerah Kota Mataram, 2020). Kondisi ini semakin memperjelas bahwa fasilitator memegang peranan krusial terhadap keberhasilan pembangunan RTG dan/atau proses rehabilitasi dan rekonstruksi secara umum.

\subsubsection{Kelompok Masyarakat}

Stakeholder berikutnya yang berasal dari masyarakat yaitu Kelompok Masyarakat (POKMAS). Melalui mekanisme rembuk warga, tim fasilitator membentuk POKMAS. POKMAS terdiri dari 10 hingga 20 kepala keluarga yang ditetapkan oleh kepala desa/lurah setempat. POKMAS dibentuk agar terwujud transparansi dan akuntabilitas di tingkat masyarakat penerima bantuan. Terbentuknya POKMAS sebagai bentuk dari adanya keterlibatan aktif dari masyarakat untuk menjamin penerima bantuan sudah tepat sasaran (Biro Komunikasi Publik Kementerian PUPR, 2018). Melalui POKMAS, masyarakat dapat saling mengecek 
penyaluran bantuan dan penggunaan yang bantuan sebagaimana mestinya (Prasetyo, 2018). Adanya peran aktif masyarakat melalui POKMAS menjadi bukti bahwa keterlibatan aktif masyarakat menjadikan proses rehabilitasi dan rekonstruksi menjadi lebih cepat dan berhasil. Hal ini seperti yang dikemukakan oleh Steinberg (2007, hlm. 166) dalam kajiannya bahwa pelibatan aktif masyarakat di proses rehabilitasi dan rekonstruksi yang menjadikan proses pembangunan menjadi berhasil dan berkelanjutan.

\subsection{Sinergi dan Kolaborasi yang Dilakukan Stakeholder}

Dari uraian ini terlihat bahwa dalam penanganan pascabencana gempa bumi di NTB, ada banyak stakeholder yang terlibat dan berasal dari beberapa sektor/multisektor, yaitu: pemerintah, dunia usaha, dan masyarakat. Setiap stakeholder memiliki tugas, peran, dan fungsinya masingmasing, yang semuanya saling mengisi dan melengkapi satu sama lain (Suleman \& Apsari, 2017, hlm. 58).

Berbagai stakebolder yang ada, seperti Kementerian Pekerjaan Umum dan Perumahan Rakyat, BRI, TNI, BPBD, Fasilitator, dan POKMAS saling bersinergi dan saling bekerja sama untuk menjalankan Instruksi Presiden Nomor 7 Tahun 2020 sehingga tujuan utama Inpres dapat terwujud. Sinergi terlihat dari bagaimana setiap stakeholder yang terlibat dalam penanggulangan pascabencana gempa bumi NTB. Seperti Kemenko PMK yang berperan mengoordinasikan berbagai kementerian/lembaga, pemerintah daerah (BPBD), TNI, BRI, fasilitator, dan masyarakat. Dalam proses rehabilitasi dan rekonstruksi, peran koordinator pelaksana sangat penting. Hal ini seperti yang terjadi pada saat terjadi bencana gempa bumi di Jawa Barat. Adanya Satlak Kabupaten Bandung dan BPBD Provinsi Jawa barat yang berperan sebagai perantara bagi semua stakeholder dalam menjalankan tugas pokok dan fungsi dalam kegiatan rekonstruksi rumah pascabencana di Kecamatan Pangalengan (Sagala dkk., 2013, hlm. 225).

Demikian juga dengan stakeholder lain, seperti Kementerian PUPR yang secara cepat merespons Inpres Nomor 5 Tahun 2018 dengan membuat desain RTG dan menyediakan fasilitator yang bertugas untuk mendampingi dan membantu masyarakat dalam memilih desain hingga membangun kembali RTG. Hal yang sama juga terjadi dengan peran besar dari TNI.

TNI hadir untuk membantu masyarakat dalam membangun RTG. Di saat pemerintah dan masyarakat mengalami kendala tidak adanya sumber daya manusia yang dapat membangun RTG, TNI hadir untuk mewujudkannya. TNI bersama masyarakat bahu membahu untuk membangun RTG sesuai dengan desain yang telah disusun sebelumnya.

Untuk menjamin akuntabilitas dan memastikan bahwa bantuan sudah tepat sasaran, proses validasi data dilakukan berganda baik oleh pemerintah daerah setempat juga BRI. Sejumlah persyaratan berupa kelengkapan administratif, pada dasarnya berfungsi untuk melakukan validasi data penerima bantuan. Hal ini dilakukan sebagai tindak lanjut atas adanya data ganda di mana satu rumah tangga tapi terdaftar di beberapa nama. Kondisi ini seperti yang dikemukakan oleh Apriyani dkk. (2020, hlm. 186) dan Priambodo dkk. (2020, hlm. 312) bahwa kolaborasi dan sinergi dari berbagai stakebolder dalam penanggulangan bencana alam berjalan dengan efektif.

Apabila dikaitkan dengan teori Pentahelix (Rachim dkk., 2020, hlm. 21) stakebolder yang terlibat di sini hanya pemerintah, dunia usaha, dan organisasi non-pemerintah/ lembaga swadaya masyarakat. Perguruan tinggi dan media masa belum hadir. Namun demikian, stakebolder yang ada menjalankan perannya dengan baik sehingga penanggulangan bencana tetap dapat berjalan optimal.

Kajian ini semakin menguatkan kajian sebelumnya bahwa banyaknya stakeholder yang terlibat saja tidak cukup. Kondisi yang serupa juga ditemui di awal pelaksanaan pemulihan bencana NTB yang berdampak pada mundurnya waktu yang mencapai 2 tahun lebih. Butuh koordinasi dan sinergi antara satu stakebolder dengan stakeholder lainnya. Ketika stakebolder tidak saling bekerja sama seperti yang terjadi pada pascabencana tsunami di Mentawai (Sinaga, 2013, hlm. 33) membuat proses rehabilitasi dan rekonstruksi menjadi terhambat dan kurang berhasil.

\section{Kesimpulan}

Kajian ini menunjukkan bahwa dalam menanggulangi pascabencana gempa bumi NTB telah dilakukan inovasi kebijakan. Inovasi yang dilakukan berupa pelaksanaan tahap rehabilitasi dan rekonstruksi terjadi pada saat transisi darurat menuju pemulihan. Inovasi ini tidak sepenuhnya berhasil, salah satu indikasinya dari segi waktu pembangunan RTG yang tidak sesuai target. Hal ini dikarenakan karena adanya ketidaksiapan pemerintah daerah, data ganda, kebingungan masyarakat, dan tidak adanya SDM untuk membangun rumah.

Menjawab berbagai permasalahan tersebut, kolaborasi dan sinergi dari berbagai stakeholder yang sudah ada semakin ditingkatkan. Kolaborasi dan sinergi terlihat dari bagaimana setiap stakeholder menjalankan peran dan tugasnya masingmasing dengan sangat baik, saling berkoordinasi dan saling mengisi satu sama lain. Pemerintah berperan dalam membuat perencanaan, menyediakan anggaran, hingga mengimplementasikan kebijakan yang telah disusun. Koordinasi dari pemerintah melalui kementerian/lembaga, TNI dan pemerintah daerah melalui BPBD berjalan dengan baik.

Dunia usaha berperan dalam mempercepat penanggulangan pascabencana. BRI sebagai perwakilan dari dunia usaha tidak hanya berperan dalam menyalurkan dana stimulan, tetapi juga membantu pemerintah dalam melakukan validasi data. Oleh karena itu, data ganda dan kendala administrasi lainnya dapat dicegah. Sementara itu, fasilitator berperan sebagai penyambung lidah antara pemerintah 
dengan masyarakat dan memfasilitasi masyarakat dalam membangun kembali rumahnya. Keterlibatan aktif masyarakat melalui POKMAS juga menjadikan proses rehabilitasi dan rekonstruksi dapat berjalan efektif. Kerja sama dari semua stakebolder yang pada akhirnya menjadikan permasalahan penanggulangan bencana gempa bumi NTB dapat teratasi dan pembangunan RTG berhasil mencapai target.

\section{Ucapan Terima Kasih}

Terima kasih penulis ucapkan kepada Kementerian Koordinator Pembangunan Manusia dan Kebudayaan, Kementerian PUPR, BNPB Pemerintah Daerah Kabupaten/Kota dan BPBD Provinsi/Kabupaten/Kota untuk semua data dalam penulisan artikel ini. Terima kasih juga kepada TNI, BRI, fasilitator, dan masyarakat NTB yang telah berjuang maksimal dalam menanggulangi bencana di NTB.

\section{Referensi}

Apriyani, L., Ngadino, A., \& Yoesmar, F. (2020). Peran Stakeholders dalam Penyelenggaraan Penanggulangan Bencana Tsunami Selat Sunda di Provinsi Lampung Tahun 2018. Simbur Cahaya, 27(2), 176-187. https://doi.org/10.28946/sc.v27i2.1044

Badan Nasional Penanggulangan Bencana. (2018). Petunjuk Pelaksanaan Bantuan Stimulan Perbaikan Rumah Korban Bencana Gempa Bumi di Provinsi Nusa Tenggara Barat. Badan Nasional Penanggulangan Bencana.

Bakti, H. K., \& Nurmandi, A. (2020). Pemulihan Pasca Bencana Gempa Bumi di Lombok Utara pada Tahun 2018. Jurnal Geografi, 12(2), 137-151. https://doi.org/10.24114/jg.v12i02.16750

Biro Komunikasi Publik Kementerian PUPR. (2018, Oktober 21). Proses Rehabilitasi dan Rekonstruksi Rumah Warga dan Fasilitas Publik Pasca Gempa NTB Terus Berjalan. Kementerian PUPR. https:// pu.go.id/berita/proses-rehabilitasi-dan-rekonstruksi-rumah-warga-danfasilitas-publik-pasca-gempa-ntb-terus-berjalan

Bryman, A. (2008). Social Research Methods (3 ed.). Oxford University Press.

Busch, N., \& Givens, A. (2013). Achieving Resilience in Disaster Management: The Role of Public-Private Partnerships. Journal of Strategic Security, 6(2), 1-19. https://doi.org/10.5038/1944-0472.6.2.1

Coppola, D. P. (2006). Introduction to International Disaster Management Elsevier.

Habibullah, \& Pudjianto, B. (2014). Gotong Royong pada Program Bantuan Stimulan Pemulihan Sosial di Mamuju, Sulawesi Barat. Sosio Konsepsia, 3(2), 17-35. https://doi.org/10.33007/ska.v3i2.363

Hediarto, I., Armawi, A., \& Martono, E. (2016). Optimalisasi Peran Kodim dalam Penanganan Tanggap Darurat Bencana Alam dan Implikasinya terhadap Ketahanan Wilayah (Studi di Kodim 0613/Ciamis Jawa Barat). Jurnal Ketahanan Nasional, 22(3), 321-333. https://doi.org/ 10.22146/jkn.15996

Hunt, S., \& Eburn, M. (2018). How Can Business Share Responsibility for Disaster Resilience? Australian Journal of Public Administration, 77(3), 482-491. https://doi.org/10.1111/1467-8500.12320

Kaku, K. (2019). Satellite remote sensing for disaster management support: A holistic and staged approach based on case studies in Sentinel Asia. International Journal of Disaster Risk Reduction, 33, 417-432. https:// doi.org/10.1016/j.ijdrr.2018.09.015

Kepala BPBD Provinsi NTB. (2021, Maret 3). Rakornas Penanganan Bencana 2021 Provinsi Nusa Tenggara Barat. Rakornas Penanganan Bencana 2021 Provinsi Nusa Tenggara Barat, Jakarta.

Kurniawan, L., Muttmainnah, L. St., Hamzah, A., \& Rozita, E. (2016). Inisiasi Sekolah/Madrasah Aman Bencana. Jurnal Riset Kebencanaan Indonesia, 2(2), 106-116.
Mohammad, Y. (2018, Agustus 12). Tanggap darurat Gempa Lombok diperpanjang. Beritagar.id. https://beritagar.id/artikel/berita/tanggapdaurat-gempa-lombok-diperpanjang

Mojtahedi, M., \& Oo, B. L. (2017). Critical attributes for proactive engagement of stakeholders in disaster risk management. International Journal of Disaster Risk Reduction, 21, 35-43. https:// doi.org/10.1016/j.ijdrr.2016.10.017

Neuman, W. L. (2006). Social Research Methods: Qualitative and Quantitative Approaches (6 ed.). Allyn \& Bacon.

Nukman, H. (2018, September 16). Dampak Gempa Lombok, Sektor Pariwisata Alami Kerugian Besar. detikTravel. https://travel.detik.com/ travel-news/d-4214277/dampak-gempa-lombok-sektor-pariwisataalami-kerugian-besar

Prasetyo, A. (2018, Oktober 18). Bantuan Rumah Korban Gempa NTB Disalurkan melalui Pokmas. Media Indonesia. https:// mediaindonesia.com/ekonomi/191650/bantuan-rumah-korban-gempantb-disalurkan-melalui-pokmas

Priambodo, A., Widyaningrum, N., \& Rahmat, H. K. (2020). Strategi Komando Resor Militer 043/ Garuda Hitam dalam Penanggulangan Bencana Alam di Provinsi Lampung. Perspektif, 9(2), 307-313. https:// doi.org/10.31289/perspektif.v9i2.3588

Pusdatinmas BNPB. (2018). Info Bencana: Informasi Kebencanaan Bulanan Teraktual. Pusdatinmas BNPB

Rachim, Abd., Warella, Y., Astuti, R. S., \& Suharyanto, S. (2020). Hexa Helix: Stakeholder Model in the Management of Floodplain of Lake Tempe. PRIZREN SOCIAL SCIENCE JOURNAL, 4(1), 20-27. https://doi.org/ 10.32936/pssj.v4i1.141

Rianto, A. (2015). Peran Badan Penanggulangan Bencana Daerah Provins Jawa Timur dalam Penanggulangan Pasca Bencana Letusan Gunung Kelud. Publika, 3(6). https://jurnalmahasiswa.unesa.ac.id/index.php/ publika/article/view/11923

Sagala, S. A. H., Situngkir, F., \& Wimbardana, R. (2013). Interaksi Aktor dalam Rekonstruksi Rumah Pasca Bencana Gempa Bumi. MIMBAR: Jurnal Sosial dan Pembangunan, 29(2), 217-226. https://doi.org/ 10.29313/mimbar.v29i2.397

Sinaga, L. C. (2013). Problematika Rehabilitasi dan Rekonstruksi Stud Kasus Pasca Bencana Tsunami Mentawai 2010. Jurnal Dialog dan Penanggulangan Bencana, 4(1), 23-34. https:/l perpustakaan.bnpb.go.id/jurnal/index.php/JDPB/article/view/61

Steinberg, F. (2007). Housing reconstruction and rehabilitation in Aceh and Nias, Indonesia-Rebuilding lives. Habitat International, 31(1), 150-166. https://doi.org/10.1016/j.habitatint.2006.11.002

Suleman, S. A., \& Apsari, N. C. (2017). Peran Stakeholder dalam Manajemen Bencana Banjir. Prosiding Penelitian dan Pengabdian kepada Masyarakat, 4(1), 53-59. https://doi.org/10.24198/ jppm.v4i1.14210

Syambudi, I. (2018, Oktober 11). Peran Fasilitator Dimaksimalkan Guna Percepat Rehabilitasi Lombok. tirto.id. https://tirto.id/peran-fasilitatordimaksimalkan-guna-percepat-rehabilitasi-lombok-c6eh

Undang-Undang Republik Indonesia Nomor 24 Tahun 2007 tentang Penanggulangan Bencana, Pub. L. No. 24 (2007).

Widyaningrum, N., Kodar, M. S., Purwanto, R. S., Priambodo, A., \& Fadlurrahman, I. (2020). Peran TNI dalam Penanggulangan Bencana Alam (Studi Kasus Peran Korem 043/Gatam dalam Penanggulangan Bencana Alam di Provinsi Lampung). Jurnal Georafflesia: Artikel Ilmiah Pendidikan Geografi, 5(1), 40-48. https://doi.org/10.32663/ georaf.v5i1.1073

Yumantoko, Y. (2019). Kolaborasi Para Pihak dalam Penanganan Destinasi Wisata Terdampak Bencana di Taman Nasional Gunung Rinjani. Jurnal Penelitian Kehutanan Faloak, 3(1), 15-28. https://doi.org/10.20886/ jpkf.2019.3.1.15-28

Zulfakriza. (2018, September 23). Melihat Kembali Gempa Lombok 2018 dan Sejarah Kegempaannya. KOMPAS.com. https:// regional.kompas.com/read/2018/09/23/11321551/melihat-kembaligempa-lombok-2018-dan-sejarah-kegempaannya 